\title{
The politics of institutional change Diverging goals for reforming the European legislature
}

\author{
Thomas König and Thomas Bräuninger
}

\section{Different criteria for joining the Union's club}

The dynamics of European integration can be looked at from two angles: the extension of the Union's legislative competencies and its enlargement by the accession of additional member states. Over the past forty years competencies have been continuously extended, in particular by the Single European Act in 1987 and the Maastricht Treaty on European Union in 1993. ${ }^{1}$ Since 1958 the process of integration has witnessed expansion from a Common Market of six to a Union of fifteen, with a population today of about 372 million. As integration progresses over the next decade it may eventually include more than twenty-seven members. This process, however, will have different implications for European countries. While both present member states and applicant countries expect to profit politically and economically from further integration, the incumbents fear that a wide enlargement will change the Union's functioning. In this contribution our concern is enlargement, and we will theoretically assess the consequences of different accession scenarios on the Union's effectiveness and member states' efficacy.

Most accession scenarios focus on the economic performance of the applicant countries (Baldwin 1994; Hagen 1997). Although all applicants from Eastern Europe have been given the status of a formal 'Accession partnership', the economic criteria of the Commission's 'Agenda 2000' proposal alone are not sufficient to determine the exact set of new members. The accession of the most promising candidates - Hungary, Poland, the Czech Republic and Estonia from Eastern Europe, and Slovenia and Cyprus from Southern Europe - will depend on their meeting exogenous and endogenous criteria: the applicants for membership not only have to be able to adhere to the aims of political, economic and monetary union, but it was acknowledged early on that the European Union itself must also prepare the institutional conditions for ensuring its proper functioning. It is feared that an extensive enlargement will dilute the Union's capacity to act when twenty or even twenty-seven member states have to reach consensus on European legislation.

With regard to the Union's effectiveness, even British Conservatives accepted the extension of member states' majority voting in European legislation, but the debate is about what exactly will constitute a legislative majority. When member 
states extended the scope of Council of Ministers' qualified majority voting in the mid-1980s - in order to complete the internal market project - the support of outvoted member states and their citizens had already been weakened. For this reason, the Amsterdam Treaty revision also aimed to increase common support by strengthening the role of the European Parliament in European legislation. In the end, member states considered the codecision procedure to be the best way to minimise the trade-off between Council qualified majority voting and parliamentary integration. However, the participation of an additional voting body is likely to decrease the Union's effectiveness once again.

Another important aspect of the Union's functioning concerns the balance between the efficacy of large and small member states. While decreasing the Council voting quota to simple majority may increase the Union's effectiveness even under the codecision procedure - it would also reduce the difference between large and small member states in terms of their individual efficacy. For this reason, France and Spain would have liked to increase large countries' voting weights, while the reunified Germany suggested applying a quorum solution, adding a population-weighted vote to the qualified majority voting quota. By and large, the debate on re-weighting caused considerable friction in the beginning. Both proposals were rejected at the Amsterdam Intergovernmental Conference. A major task of the Nice Intergovernmental Conference in December 2000 was, therefore, to resolve the institutional issues left open in Amsterdam that needed to be settled before enlargement. In the end, the Nice Treaty established a new distribution of weighted votes, increased the majority threshold and introduced two additional hurdles for decision-making, a member state and a population quorum (Felsenthal and Machover 2001).

The following analysis examines the Union's functioning under different reform proposals and for different steps of the enlargement process. It hereby confronts both aspects of institutional reform, the Union's effectiveness concerning functional and parliamentary integration as well as member states' efficacy in terms of re-weighting their votes and modifying the majority threshold. Like Lane and Mæland (in Chapter 7 of this volume) we measure the Union's effectiveness under different procedures using the Coleman index, and we also use our inclusiveness index to outline the corresponding efficacy of member states (König and Bräuninger 1998). However, while Lane and Mrland stress the number of feasible winning coalitions when applying the non-normalised Banzhaf index, we do not find evidence for introducing Council simple majority voting. The re-weighting debate and the provisions of the Nice Treaty rather indicate that large member states are interested in maintaining their ability to preserve the status quo. We accordingly argue that member states consider not only the number of feasible winning coalitions but also their ability to block decisions, which means their performance to preserve the status quo.

The remainder of this contribution is divided into four sections. In the following section we outline the reasons for parliamentary integration and the transformation from unanimity to weighted qualified majority voting in the Council. We discuss the two major approaches used to explain these changes, which became apparent during the mid-1980s. Next, we present our conception of 
legislative actors and inter-institutional winning coalitions in order to approach the member states' choice of voting rules. With regard to further enlargement we argue that two waves of accessions are likely. We then introduce our concept of inclusiveness, referring to changes in effectiveness and efficacy. Finally, we draw our conclusion from enlargement scenarios with respect to modifications of the standard and codecision procedure.

\section{From unanimity to qualified majority in multi-cameral settings}

Despite the formal provisions of the Treaty of Rome for Council majority voting, the Luxembourg Accords of 1966 - often called an intergovernmental agreement to disagree on majority voting - granted all member states veto power up to the mid-1980s (Kapteyn and Verloren van Themaat 1990: 249). In 1986 the Council stated in the Official Journal that forty legislative proposals had been adopted by qualified majority voting - tripling the total figure for 1985 (WQ 1121/86, C306/42). By the end of 1986, the Council increased the total figure to more than one hundred qualified majority decisions, in particular on single-market issues (Nugent 1994: 147). Compared to unanimity, Council qualified majority decision-making facilitates European legislation, but the remarkable change begs the question as to why the member states allowed more majority voting.

Two particular events were important for the transition to qualified majority voting in the Council: first, the member states' intention to adopt 282 measures for completing the internal market that had been documented in the 1985 White Paper; second, the so-called 'southern enlargement' with the accession of Greece in 1981 and of Spain and Portugal in 1986, which increased the socio-economic variation among the member states. Similar to the contemporary discussion about the accession of Eastern and Southern European countries, most member states were convinced of the need to increase the effectiveness of European decision-making by turning away from the restrictive unanimity rule. For functional integration the qualified majority criterion was applied in the Council, setting a voting threshold of about 71.2 per cent of all votes. According to the Nice Treaty's Declaration on the qualified majority threshold and the number of votes for a blocking minority in an enlarged Union, this will move to a maximum of 73.9 per cent when all twelve candidate countries have acceded.

In addition to increasing the Union's effectiveness by lowering the voting quota, the provision for qualified majority voting also discriminates between member states according to the allocation of voting weights: in contrast to the one-state-one-vote principle, the Council qualified majority voting rule discriminates on member states' efficacy by distinguishing between large and small member states. Voting weights are approximately related to the size of the member states' population, although France and Germany initially preferred a weighting according to member states' economic power. ${ }^{3}$ In studying member states' choice of voting rules, one must take into consideration both the Union's effectiveness and member states' individual efficacy.

Even though effectiveness has been increased by applying the qualified majority criterion, the realisation of the internal market project has provoked much 
criticism of European legislation. In Britain, European legislation has been attacked for its over-regulation, manic harmonisation and state subsidies, while the French criticise its liberalism, privatisation and laissez-faire economics. Citizens increasingly dislike the European in concert with national bureaucrats coordinating intergovernmental collaboration in internal market, agricultural and trade affairs without any parliamentary control of European legislation. Moreover, treaty reforms have to be ratified by national parliaments, which led to demands for parliamentary control of the government-biased European legislation. For these reasons, the role of the European Parliament was strengthened when the Council moved to qualified majority voting in the mid-1980s and, today, about twenty procedures apply to various policy areas. In order to increase transparency the fifteen members have agreed, in principle, to reduce the number and the complexity of European legislative procedures.

Basically, we find four procedures in various modifications. According to the consultation procedure established by the Treaty of Rome in 1957, European legislation originates with the Commission, and the Council adopts the proposal by simple, qualified majority or unanimity, depending on the specific treaty provision. In the consultation procedure, the European Parliament gives its opinion, Commission and Council explain their opinion to the European Parliament, but they do not operate through Parliament. The cooperation and assent procedures were introduced in 1987 and the codecision procedure was established in 1993; the names of these procedures refer to parliamentary rights in European legislation. All of these procedures establish complex multi-cameral systems of European decision-making affecting the trade-off between the Union's effectiveness and the efficacy of participating actors. This complexity has attracted many scholars applying various approaches to power distribution and agenda setting in European multi-cameral decision-making.

For the study of multi-cameral decision-making, most approaches are more concerned with the choice within rules than with the choice of voting rules. Hence they tend to concentrate on the impact of either the differences between member states or the inter-institutional interaction of the Commission, the Council and the European Parliament on European legislation. Considering the actors' different voting weights in the case of majority voting, relative voting power analyses have focused on actors' relative ability of being decisive in forming winning coalitions. Their main findings concern the decreasing power of larger member states due to enlargements despite weighted qualified majority voting (Brams and Affuso 1985; Lane and Mrland 1995; Hosli 1996; Sutter 2000). Others emphasise parliamentary groups' relative ability to put forth their policy preferences in European Parliament decision-making (Lane et al. 1995). Based on extensive form games, spatial analyses call the analytical usefulness of power index analysis fundamentally into question. One argument is that recent power index applications have ignored the strategic interaction between the Commission, the Council and the European Parliament in the passage of European legislation when focusing on the relative power distribution between member states in the Council (Garrett and Tsebelis 1996: 270). Except for Article 148.2b EC, all European legislative procedures requirè a Commission proposal 
that must ultimately be adopted by the member states with unanimity, qualified or simple majority (Steunenberg 1994). Another argument is that spatial studies take into account both actors' policy preferences and strategic interaction between European voting bodies, while voting power indices ignore the spatial location of member states' policy preference. Studying the choice within voting rules, spatial analyses outlined that the European Parliament is only granted conditional agenda-setting power in the cooperation procedure (Steunenberg 1994; Tsebelis 1994, 1996), but blocking power in the codecision (Schneider 1995) and assent procedures (Tsebelis and Garrett 1996).

Both approaches to European decision-making, however, have shortcomings when we consider the choice of European voting rules. Voting power studies usually focus on either member states' or parliamentary groups' relative ability to be decisive in forming winning coalitions. Since actors have the same relative ability to be decisive under unanimity and unweighted majority voting, relative power indices do not take account of the distinction between majority and unanimity voting, which define the Union's effectiveness. By contrast, spatial models require knowledge of procedural constraints, the location of actors' policy positions, and of the status quo. However, constitutional choice precedes policy choice, and constitutional actors do not know ex ante the dimensionality and location of their policy positions, the status quo, or the other actors involved in future decision-making processes (Buchanan and Tullock 1962: 78).

Constitutional actors are not certain of the exact content of prospective proposals, their exact number or their spatial location, which may favour or hinder majority building. This is the major difference between the choice within and the choice of voting rules. In order to approach member states' constitutional choice of voting rules, we therefore focus on two aspects of their expectations: the effectiveness of decision-making and their individual efficacy. Member states take into particular consideration the passing of a Commission proposal, the decision probability in European legislation, the formation of a majority coalition in each voting body, their expected contribution to the Union's effectiveness, etc. To study the effects of different voting rules on the Union's effectiveness and member states' efficacy, we must first identify the procedural settings and second, the actors of European legislative decision-making in the present and future Union.

\section{Actors and winning coalitions of the present and future Union}

According to the 1996 Turin conclusions of the European Council, the subsequent institutional reforms at the Amsterdam and Nice Intergovernmental Conferences aimed to increase the effectiveness and transparency of European legislation, with the goal of increasing parliamentary legitimacy (Steunenberg 1997: 2). In order to raise parliamentary involvement, the modified codecision procedure (Conference of Representatives 1997: 122-4) proved to be the most promising voting procedure, requiring not only the consent of the European Parliament, but also giving the agenda-setting function to parliamentary delegates in the conciliation committee. Its effectiveness is increased by lowering the 
Council voting quota, thereby allowing for the exclusion of some member states' policy positions. The Amsterdam Treaty proposes to apply the standard and the modified codecision procedures extensively, while the assent procedure should be used for legislation on external relations (Conference of Representatives 1997: 119). The assent procedure does not establish an agenda-setting function for the European Parliament, which can only adopt or reject a proposal. We investigate the standard and modified codecision procedures as ideal types to study the impact of institutional politics for reforming the Union's framework.

The purpose of procedural settings is to set up formal voting rules on winning or losing, which are essential in politics. The bi- or tricameral settings of the standard and codecision procedures complicate the identification of winners and losers because they combine voting bodies as collective veto players with internal coalition building processes in the Commission, the Council and the European Parliament. We conceive these internal coalition processes as subgames, which are combined on the compound level of a bi- or multi-cameral game. The bicameral standard procedure consists of the Commission and Council subgame, while the codecision procedure adds the European Parliament subgame. Their coalition building processes differ with regard to the number of subgame actors and the corresponding voting quota. ${ }^{4}$ In order to make enlargement effects comparable, we conceive of the European Parliament as a constant voting body consisting of two major and two minor parliamentary groups. Each major group is provided with two votes and each minor group has one vote to fulfil the absolute majority criterion. ${ }^{5}$

The procedural settings define the combination of subgames with all actors necessary to adopt a proposal. However, identifying these actors is rather complicated for two reasons: first, the Council's and the European Parliament's voting rules vary considerably. ${ }^{6}$ Second, the role of the Commission is rather speculative. ${ }^{7}$ We investigate the compound game in a bicameral setting requiring consent between the Commission and the Council under standard conditions. We investigate it as a semi-tricameral setting under the (modified) codecision procedure, between the Council, the European Parliament, and in part the Commission, as long as the European Parliament has no decisive structure. ${ }^{8}$ Because the codecision procedure includes a non-decisive European Parliament, an additional set of winning coalitions is introduced: the first case of the original codecision procedure encompasses the Commission, a qualified majority of Council votes and at least half of the parliamentary votes; the second case consists of the unanimous member states with at least the absolute majority of parliamentary votes. The modified codecision procedure introduced by the Amsterdam Treaty has changed this second case: it decreases the Council's voting quota to a qualified majority. Hence, the combination of two cases of winning coalitions leads to a semi-tricameral system, since the Commission can be excluded from the second case under the codecision procedure.

Whilst the Amsterdam Treaty has modified the interplay of organs, it postponed the issues of institutional reform of the Council of Ministers. Two proposals for reforming its legislative procedures have been debated. According to the French proposal, large member states should be allocated twenty-five votes, 
the smallest member states three votes, and the current voting quota should be retained. ${ }^{9}$ The German proposal suggested retaining the pre-Nice allocation of votes but introduced an additional quorum that should provide for the representation of at least 60 per cent of the Union's total population. Both reform options have been rejected. The European Council finally succeeded at its Nice meeting in establishing a new distribution of weighted votes and two additional prerequisites for decision-making. ${ }^{10}$ Article 3.la(i)-(ii) of the Nice Treaty's Protocol on the Enlargement of the European Union (Conference of Representatives 2001) states that acts of the Council shall require for their adoption a qualified majority of weighted votes in favour

cast by a majority of members. ... When a decision is to be adopted by the Council by a qualified majority, a member of the Council may request verification that the member states constituting the qualified majority represent at least 62 percent of the total population of the Union. If that condition is shown not to have been met, the decision in question shall not be adopted.

\section{Two waves of enlargement}

The sets of winning coalitions represent the cornerstone of our analysis of the present Union's effectiveness and member states' efficacy, but we still have to identify the set(s) of potential member states in a further enlarged Union. During the Copenhagen meeting of the European Council in 1993, a French proposal specified the formal requirements for membership, as repeated by the Commission's Agenda 2000 and laid down in Article $O$ of the Treaty on the European Union. This admission catalogue not only includes measurements of economic development and a functioning market economy, it also requires a quantifiable level of social protection, control over public debt and inflation, an open economy, a modern fiscal system and the administrative capacity to implement European legislation (Baldwin 1994: 155). The background is that, from today's perspective, the accession of all applicants would increase the Union's population by around 30 per cent but its GDP by only 4 per cent.

Regarding the Union's budget financing, structural funds and Common Agricultural Policies, the risks and costs of further enlargement pose a considerable problem not only for potential, but also for actual members spending 1.27 per cent of their GDP for European budget affairs (Streit and Voigt 1996). Europe's agricultural sector and its poorer regions currently receive about 80 per cent of all European spending and, since the Eastern applicants are populous, poor and agricultural, the unchanged Common Agricultural Policies would increase the Union's budget by nearly ECU 40 billion. Moreover, extending the structural funds would raise the annual costs by ECU 26 billion (Baldwin 1995: 477). Tax raising, however, is not a feasible policy to cope with these deficits; enlargements will most probably be accompanied by spending cuts. The eastward enlargement is therefore less favoured by southern, poor and agricultural member states, while northern incumbents expect gains from extending their trade relations (Michalski and Wallace 1992: 54). 
Under these conditions, two aspects are important for delineating the set of potential member states. First, Article 2 of the Draft Treaty's protocol on the institutions (Conference of Representatives 1997: 118) restricts the number of European member states to twenty without institutional reform. Second, the economic and geopolitical situation of applicant countries not only has to take into account their deliverance from Russian hegemony but also the ongoing crisis in the Southern hemisphere. Therefore, we expect two waves of enlargement. The first wave will be limited to five new members, and the second wave will contain the remaining seven applicants. Of the first wave, only Slovenia is meeting the economic preconditions, but it is likely that Hungary, Poland and the Czech Republic will also make up the next group to achieve accession due to their geographical proximity and their institutional embedding in the Visegrad-4 group (Hagen 1997: 375). Compared to Latvia and Lithuania, with their Russian minorities, Estonia had started to advertise itself as less of a Baltic and more of a Scandinavian state, and we expect that it will be pushed as the fifth new member of the first wave by Sweden and Finland.

In contrast to the Commission's Agenda 2000 we do not consider Cyprus as an entrant in the first wave since its participation will presuppose Greek and Turkish support. Malta has just renewed its application and is also considered an inconstant candidate. ${ }^{11}$ Besides Latvia, Lithuania and Cyprus, Slovakia has already been excluded from the first wave, because of its unwillingness to guarantee minority rights for its Hungarian and Czech population. Moreover, Bulgaria and Romania will have to wait for the second wave, despite the French support for Romania's membership. Since both waves will change the Union's effectiveness, present members have made these future enlargements dependent on the Union's ability to reform its institutional framework.

\section{Considering the consequences of enlargement}

For Europe, enlargement is certainly an historic opportunity to end the artificial division of Europe, and therefore it is interesting to look for strategies that may more appropriately serve the cause of institutional reform of future European legislation. In the following we argue that two aspects have to be considered: the Union's effectiveness and current member states' efficacy.

\section{The Union's effectiveness in decline}

In conducting an analysis of the Union's institutional reform, we are concerned with problems about how to measure the prospective change of effectiveness and efficacy by further accessions. Theoretically, the effectiveness of decision-making is determined by two components: the number of participants and the voting rule applied. Unanimity restricts the decision probability of an $n$-actor committee to the single favourable winning coalition of all feasible $2^{n}$ coalitions, whereas simple majority permits about half of all coalitions to make binding decisions. Due to different membership size and voting quotas of the Union's voting bodies, we measure effectiveness using decision probability. According to 
Coleman (1971: 278), we define the decision probability of a voting rule as the ratio between the number of winning coalitions (able to alter the status quo) and all feasible coalitions. ${ }^{12}$ Applied to the Union's procedures, the decision probability in the standard procedure involving the Commission and a unanimous Council decreased from 0.0078 for the original six to almost 0.0001 for the twelve member states. This fundamental change indicates why member states decided to decrease the Council voting quota in order to complete the internal market up to the end of 1992. In the mid-1980s, when the twelve member states extensively started to apply qualified majority voting in the standard procedure, their decision probability was higher than ever before. In the following we use this value as the baseline value for comparison of decision probability.

Table 5.1 shows the changes in comparison to the decision probability of the standard procedure under Council qualified majority voting in $1986 .^{13}$ The columns show changes due to past and future enlargements as well as different reform options of redistributing member states' voting weights, which have been discussed at the Amsterdam and the Nice Intergovernmental Conferences.

Compared to 1986, with twelve members, the accession of new members represents a continuous decrease of the decision probability to about 79 per cent in 1995, 47 per cent with the first and 29 per cent with the second wave of enlargement under qualified majority voting if the old, pre-Nice weighting of member states' votes were retained. Under unanimity decision-making becomes rather unlikely. The accession of Austria, Finland and Sweden in 1995 already limited the Union's effectiveness, but forthcoming enlargement will almost reverse the positive effect of the transition from unanimity to Council qualified majority voting. The accession of Poland with eight votes, Hungary and the Czech Republic with five votes each, and Estonia and Slovenia with two votes each would halve present decision probability. With the accession of Romania with seven votes, Bulgaria with four votes, Lithuania and Slovakia with three votes each, Cyprus, Latvia and Malta with two votes each, decision probability would again be reduced by almost the same amount.

While decision probability in the original codecision procedure, as a result of the additional parliamentary inclusion, was always lower than in the standard procedure, the modified codecision procedure increases the Union's effectiveness by reducing the Council's voting quota. Its decision probability is similar to that of the consultations procedure with qualified majority voting. If parliamentary participation will indeed raise common support, the modified codecision procedure may presently guarantee proper functioning because the positive effect of Council majority voting on the Union's effectiveness will not be reversed by the inclusion of the European Parliament.

However, enlargement would considerably decrease the Union's overall effectiveness. The dramatic decline of decision probability indicates the need for institutional reform. For this purpose, the preparatory documents for the Amsterdam summit offered two proposals that were finally rejected. Applying these proposals to an enlarged Union of twenty members, the French proposal would have provided more frequent policy change, shifting decision probability to 60 per cent in the consultation and 37 per cent in the original codecision 


\begin{tabular}{|c|c|c|c|c|c|c|c|c|c|c|}
\hline & \multirow{2}{*}{$\begin{array}{l}1986-95 \\
(12 \text { states }) \\
\text { Pre-Nice } \\
\text { provisions }\end{array}$} & \multirow{2}{*}{$\begin{array}{l}1995- \\
(15 \text { states }) \\
\text { Pre-Nice } \\
\text { provisions }\end{array}$} & \multicolumn{4}{|l|}{$\begin{array}{l}\text { First wave } \\
\text { (20 states) }\end{array}$} & \multicolumn{4}{|l|}{$\begin{array}{l}\text { Second wave } \\
\text { (27 states) }\end{array}$} \\
\hline & & & $\begin{array}{l}\text { Pre-Nice } \\
\text { provisions }\end{array}$ & $\begin{array}{l}\text { French } \\
\text { proposal }\end{array}$ & $\begin{array}{l}\text { German } \\
\text { proposal }\end{array}$ & $\begin{array}{l}\text { Post-Nice } \\
\text { provisions }\end{array}$ & $\begin{array}{l}\text { Pre-Nice } \\
\text { provisions }\end{array}$ & $\begin{array}{l}\text { French } \\
\text { proposal }\end{array}$ & $\begin{array}{l}\text { German } \\
\text { proposal }\end{array}$ & $\begin{array}{l}\text { Post-Nice } \\
\text { provisions }\end{array}$ \\
\hline $\begin{array}{l}\text { Consultation/qualified } \\
\text { majority }\end{array}$ & 1.00 & 0.79 & 0.47 & 0.60 & 0.47 & 0.46 & 0.29 & 0.38 & 0.29 & 0.21 \\
\hline Consultation/unanimity & 0.002 & 0.0003 & 0.00001 & 0.00001 & 0.00001 & 0.00001 & 0.00000010 & 0.0000001 & 0.0000001 & 0.0000001 \\
\hline Codecision (original) & 0.63 & 0.50 & 0.30 & 0.37 & 0.30 & - & 0.18 & 0.25 & 0.18 & - \\
\hline Codecision (modified) & - & 0.79 & 0.47 & 0.60 & 0.47 & 0.46 & 0.29 & 0.38 & 0.29 & 0.21 \\
\hline
\end{tabular}

Note: Decision probability of 1986 Consultation procedure (with Council qualified majority) is baseline $(\mathrm{P}=0.0491)$.

Weighting of votes and thresholds in the Council:

- Pre-Nice provisions, 1986-95: France (10), Germany (10), Italy (10), United Kingdom (10), Spain (8), Belgium (5), Greece (5), Netherlands (5), Portugal (5), Denmark (3), Ireland (3), Luxembourg (2); 1995-: Austria (4), Sweden (4), Finland (3), threshold: 54/76 weighted votes; first wave: Poland (8), Czech Republic (5), Hungary (5), Estonia (2), Slovenia (2), threshold: 62/87 weighted votes; second wave: Romania (7), Bulgaria (4), Lithuania (3), Slovakia (3), Cyprus (2), Latvia (2), Malta (2), threshold: 94/132 weighted votes.

- French proposal, first wave: France (25), Germany (25), Italy (25), United Kingdom (25), Poland (20), Spain (20), Netherlands (12), Belgium (10), Czech Republic (10), Greece (10), Hungary (10), Portugal (10), Austria (8), Sweden (8), Denmark (6), Finland (6), Ireland (6), Estonia (3), Luxembourg (3), Slovenia (3), threshold: 174/245; second wave: Romania (16), Bulgaria (8), Lithuania (6), Slovakia (6), Cyprus (3), Latvia (3), Malta (2), threshold: 206/290.

- German proposal: pre-Nice provisions plus additional quorum of at least 60 per cent of total population.

- Post-Nice provisions: France (29), Germany (29), Italy (29), United Kingdom (29), Poland (27), Spain (27), Netherlands (13), Belgium (12), Czech Republic (12), Greece (12), Hungary (12), Portugal (12), Austria (10), Sweden (10), Denmark (7), Finland (7), Ireland (7), Estonia (4), Luxembourg (4), Slovenia (4), threshold: $215 / 296$ weighted votes of at least $11 / 20$ states representing at least 62 per cent of total population; second wave: Romania (14), Bulgaria (10), Lithuania (7), Slovakia (7), Cyprus (4), Latvia (4), Malta (3), threshold: 255/345 weighted votes of at least $14 / 27$ states representing at least 62 per cent of total population. 
procedure as compared to the 1986 baseline. With the second enlargement, however, the decision probability would again decrease to 38 per cent and 25 per cent, respectively. Re-weighting, in particular with parliamentary participation, cannot guarantee a proper functioning of European legislation. The German proposal of an additional quorum would have had the same effects on decision probability as the pre-Nice provisions and would not have provided a means to speed up the legislative processes either.

The Nice Treaty introduces even higher hurdles for decision-making in the Council, namely a member state and a 62 per cent population quorum. As a result the post-Nice provisions will decrease decision probability in both consultation and the (modified) codecision procedure. Due to the increase of the threshold in the pace of enlargement, this loss in efficiency will be highest in a Union of twenty-seven member states. In sum, the French proposal would have slightly reduced the gridlock danger, but no significant effort in securing the Union's functioning can be made as long as the 71.2 per cent Council voting quota prevails. The German proposal would have had no substantial effect, whereas the post-Nice provisions will even increase the danger of legislative gridlock. However, a lowering of the voting quota would fundamentally change the current distribution of member states' efficacy, as established by their different voting weights.

\section{Member states' efficacy in change}

In order to provide enough room for manoeuvre in case of enlargement, there seems to be only one way of reforming the procedural settings: decision probability can be raised by decreasing the Council voting quota. The question is what should constitute a majority and/or whether or not a new distribution of voting weights should be used to balance the existing differences between member states. Under unanimity all member states have the same efficacy on European decision-making, while weighted majority voting puts larger member states at an advantage. When voting weights establish differences between member states' efficacy, some are more likely to be in a majority position than others. Decreasing the voting quota will certainly modify this distribution. In order to show this effect, we analyse the changes of individual inclusiveness compared to the 1986 baseline model. According to our index of decision probability we measure the efficacy of an actor by the inclusiveness, i.e. as the number of times an actor participates in winning coalitions in relation to the number of all feasible winning coalitions (Bräuninger 1996: 42). ${ }^{14}$ If an actor can be excluded from any feasible winning coalition, the inclusion of its policy position is determined only by luck. Thus, the actors holds a so-called dummy player position and its efficacy is 0.5 , the smallest possible value. By contrast, if an actor cannot be excluded from any feasible winning coalition the actor is a veto player with the maximal efficacy of 1.0 .

Table 5.2 shows the changes by lowering the voting quota with respect to member states' efficacy after the second wave of enlargement. In 1986, the efficacy of large member states was about 0.856 , whereas Luxembourg was still 
Table 5.2 Individual efficacy in the consultation and modified codecision procedure under different settings (inclusiveness indices)

\begin{tabular}{|c|c|c|c|c|c|c|}
\hline & \multirow{2}{*}{$\begin{array}{l}1986-95 \\
\text { (12 states) } \\
\text { Consultation } \\
\text { Pre-Nice } \\
\text { provisions }\end{array}$} & \multicolumn{5}{|c|}{$\begin{array}{l}\text { Second wave } \\
\text { (27 states) }\end{array}$} \\
\hline & & \multicolumn{5}{|c|}{ Codecision (modified) } \\
\hline Commission & 1.000 & 0.625 & 0.625 & 0.625 & 0.625 & 0.625 \\
\hline Spain, Poland & 0.801 & 0.811 & 0.818 & 0.811 & 0.885 & 0.614 \\
\hline Romania & - & 0.776 & 0.761 & 0.776 & 0.721 & 0.599 \\
\hline Netherlands & 0.684 & 0.703 & 0.699 & 0.703 & 0.706 & 0.570 \\
\hline \multicolumn{7}{|l|}{ Belgium, Czech Republic, Greece, Hungary, } \\
\hline Portugal & 0.684 & 0.704 & 0.667 & 0.704 & 0.691 & 0.570 \\
\hline $\begin{array}{l}\text { Cyprus, Estonia, Luxembourg, Latvia, } \\
\text { Malta, Slovenia }\end{array}$ & 0.550 & 0.583 & 0.551 & 0.583 & 0.565 & 0.528 \\
\hline Parliament group with 2 votes & 0.500 & 0.750 & 0.750 & 0.750 & 0.750 & 0.750 \\
\hline Parliament group with 1 vote & 0.500 & 0.625 & 0.625 & 0.625 & 0.625 & 0.625 \\
\hline
\end{tabular}


provided with a value of 0.550 . Both parliamentary actors had a dummy player position in the consultation procedure and were only included in majority building by chance. Compared to the baseline values we find that the two Amsterdam reform proposals and the pre-Nice weighting under qualified majority would have modestly redistributed present member states' efficacy in the case of a Union of twenty-seven. The efficacy value of larger member states like France, Germany, Italy and the United Kingdom would increase modestly; Spain and Poland, and particularly the Netherlands would also profit from these versions, while both Amsterdam reform proposals hardly intended to decrease the efficacy of all medium-sized states.

By privileging larger member states, the French proposal would have slightly increased the asymmetry between large and small members. This proposal for institutional reform can be considered a trade-off for the small (northern) members' goal of an early Eastern enlargement, while the German proposal would have no redistributive effects. Larger medium-sized states like Belgium or Greece and small states, like Luxembourg, would have even profited from the pre-Nice settings and the German proposal. But there is no significant difference between pre-Nice settings and the two Amsterdam options, regarding either member states' efficacy or the Union's effectiveness. This means that none of these provisions would have provided a way out of improper functioning.

This changes, however, if we move to post-Nice provisions. Figure 5.1 shows the individual efficacy in the modified codecision procedure under the pre- and

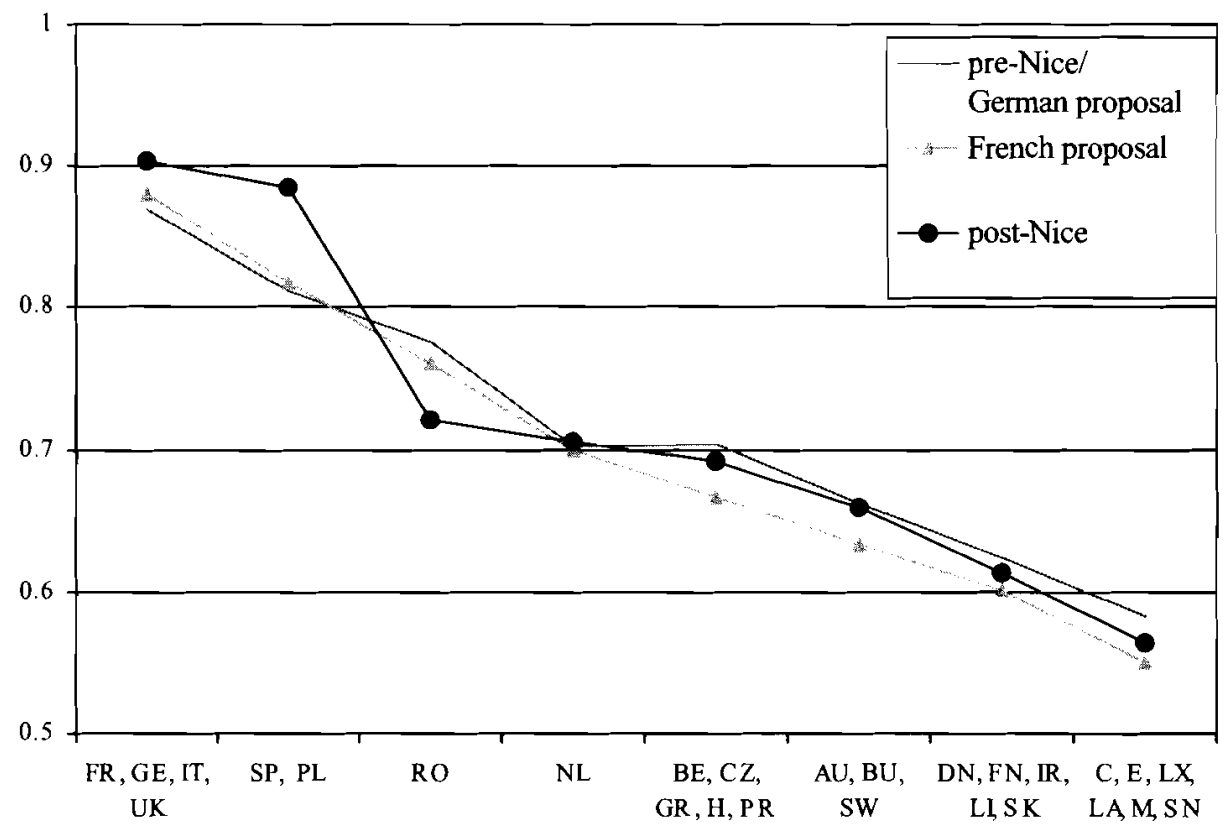

Figure 5.1 Consequences of reform options and the Nice reform on member states' inclusiveness. 
post-Nice provisions, the French and the German proposals. The results suggest that the Nice reform benefits large member states at the expense of smaller incumbents and most (rather small) accession countries. Compared to the preNice setting, the big four as well as Spain and Poland will increase their efficacy by 15 per cent while all other member states will lose. The sharp divide is between Spain and Romania, the efficacy of the latter is quite similar to that of the Netherlands.

The last column of Table 5.2 shows member states' efficacy on simple majority voting in the Council but without any modifications to the pre-Nice voting weights. Lowering the quota would have accordingly raised the decision probability in the codecision procedure about ten times higher than the 1986 baseline value of qualified majority voting in the consultation procedure. Nevertheless, simple majority would reduce large member states' efficacy to about 0.644 , while small member states would have to bear only modest losses as compared to the 1986 distribution. Assuming that the baseline value indicates an acceptable trade-off between effectiveness and efficacy, we cannot expect member states to adopt this option, since they would become much more similar under simple majority rule.

\section{Conclusion}

The accession of Eastern and Southern European countries presupposes reform of the Union's institutional framework; originally developed by the six founding states to regulate policies as positive-sum games. New accessions will change both the effectiveness of the European decision-making system and the efficacy of member states. Today's member states have therefore looked for procedural settings to preserve proper functioning with respect to both the Union's capacity to act and their influence on European decision-making. With regard to the Union's effectiveness, even British Conservatives accepted the extension of member states' majority voting in European legislation, but the debate remained about what exactly constitutes a legislative majority. Reforming the voting rules by lowering the voting quota and re-weighting has caused considerable friction. Since all previous proposals have been rejected at the Amsterdam conference, member states had postponed the Union's institutional reform and finally agreed on a re-weighting of votes at the Intergovernmental Conference, held at Nice in December 2000.

Our results suggest that the Nice reform heavily reflects the interests of the large incumbents, in particular of France and Germany which provided themselves with the power to block about 90 per cent of all decisions. Since the efficacy of all other member states is reduced rather modestly, the large member states' increase also comes at the expense of the Union's effectiveness. This poses a serious threat to the proper functioning of the European Union. From our analysis it is clear that neither the French nor the German reform proposal, nor the post-Nice setting guarantee proper functioning as long as member states fail to accept a lower Council voting quota, particularly in the event of further enlargement. 


\section{Notes}

1 For an overview, see König (1996: 556).

2 EC 622/98, OJC L85, 20/03/98, 1-2.

3 See Garrett (1992: 546) for a discussion about the distribution of voting weights. See also Lane et al. (1995: 395), and Widgrén (1995: 78).

4 Concerning the coalition building in the Commission subgame, we argue that each Commissioner is provided with his or her own portfolio, carries the main leadership responsibility, and is independent of the Commission President in determining how to act on European legislative decisions. For this reason, we conceptualise the Commission as a unitary actor in European legislation with the responsible Commissioner as its agent (see also Spence 1994: 92; Westlake 1994: 9). In the Council, the governments of the member states are represented by delegates mediating between their own governments and those of other delegates (Johnston 1994: 27). National governments instruct their delegates, who then cast their votes homogeneously in the Council (Sabsoub 1991: 40). In the European Parliament the political group affiliation of parliamentary representatives has proved to dominate coalition formation so that the political groups can be conceived as European Parliament entities with weighted votes.

5 See König (1997: 40), for values of parliamentary groups. Furthermore, simplifying the European Parliament this way does not obstruct our findings. First, effectiveness is rarely affected by the number of actors when an absolute majority rule is applied, and second, member states' individual efficacy is invariant when the European Parliament is added as an additional voting body.

6 The Council subgame offers two majority criteria under the standard and codecision procedures, since amendments always require unanimity among member states. Under the codecision procedure, the European Parliament may take action or no action. Preventing endorsement by no action slightly decreases the majority criterion, since the European Parliament has always been a voting body consisting of an equal number of representatives.

7 According to Article $155 \mathrm{TEU}$, the Commission holds the exclusive right to initiate legislation and the right to modify a proposal at any point of procedure (Article 189a.2 TEU), thereby making the Commission the agenda setter. Moreover, the Commission also has the right to withdraw, if the proposal's object is felt to be emasculated by amendments (Usher 1994: 148). By contrast, Tsebelis and Garrett (1996: 13) argue that the Commission loses its agenda-setting power under the modified codecision procedure.

8 A voting body is decisive when the complement of a losing coalition is a winning one and vice versa.

9 See Consolidated Draft Treaty Texts (1997: 113) and footnotes of Table 5.1.

10 See footnotes of Table 5.1.

11 The application of Malta was frozen between October 1996 and September 1998.

12 Formally, we represent the legislative procedure as a simple game, i.e. a map $v$ where for any coalition $S$ of the player set $N, v(S)=1$ if the coalition $S$ is winning, and $v(S)=$ 0 otherwise. Hence we assume that actors do not know their future preferences and, therefore, consider all Yes and No votes to be equally probable. Under these assumptions, the decision probability $P(v)$ is

$$
P(v)=\frac{\sum_{S \subseteq N} v(s)}{2^{n}}
$$

In a committee of four actors, for example, $2^{4}=16$ coalitions of supporting actors are conceivable. Applying unanimity the decision probability is $1 / 16(0.06)$ because only the grand coalition of all actors may change the status quo. Under simple majority the decision probability increases to $5 / 16(0.31)$, since the possible exclusion of a single actor offers a total of five winning coalitions. 
13 All indices are obtained using the program IOP 2.0 (Bräuninger and König 2001).

14 Formally, the inclusiveness of actor $i$ in the game $v$ is

$$
\omega_{i}(v)=\frac{\sum_{s \subseteq N, i \in S} v(s)}{\sum_{s \subseteq N} v(s)}
$$

In a four-actor-committee the inclusiveness of each actor is 1.0 under unanimity. Applying simple majority, the individual inclusiveness decreases to $4 / 5(0.80)$ since each actor can be excluded from one out of five winning coalitions. Increasing the number of the committee to six members, inclusiveness of each actor is still 1.0 under unanimity, but it decreases to 16/22 (0.73) since each actor can be excluded from 6 out of 22 winning coalitions.

\section{References}

Baldwin, R. (1994) Towards an Integrated Europe, London: Centre for Economic Policy Research.

Baldwin, R.E. (1995) 'The Eastern enlargement of the European Union', European Economic Review 39: 474-81.

Brams, S.J. and P. Affuso (1985) 'New paradoxes of voting power on the EC Council of Ministers', Electoral Studies 4: 135-39.

Bräuninger, T. (1996) 'Die Modellierung von Entscheidungsverfahren internationaler Organisationen am Beispiel der Meeresbodenbehörde', Mannheim: unpublished thesis.

Bräuninger, T. and T. König (2001) Indices of Power IOP 2.0 [computer program], Konstanz: University of Konstanz [http://www.uni-konstanz.de/FuF/Verwiss/koenig/IOP.html].

Buchanan, J.M. and G. Tullock (1962) The Calculus of Consent: Logical Foundations of Constitutional Democracy, Ann Arbor: University of Michigan Press.

Coleman, J.S. (1971) 'Control of collectivities and the power of a collectivity to act', in B. Lieberman (ed.) Social Choice, New York: Gordon and Breach, 269-99.

Conference of the Representatives (1997) Draft Treaty of Amsterdam. Conference of the Representatives of the Governments of the member states, 19 June 1997, Brussels $(\mathrm{CONF} / 4001 / 97)$.

Conference of the Representatives (2001) Draft Treaty of Nice. Conference of the Representatives of the Governments of the member states, 30 January 2001, Brussels (SN/1247/01EN).

Consolidated Draft Treaty Texts (1997) 30 May 1997, Brussels (SN/600/97).

Felsenthal, D. and M. Machover (2001) 'The treaty of Nice and qualified majority voting', Social Choice and Welfare 18: 431-64.

Garrett, G. (1992) 'International cooperation and institutional choice', International Organization 46: 533-60.

Garrett, G. and G. Tsebelis (1996) 'An Institutional Critique of Intergovernmentalism', International Organization 50: 269-99.

Hagen, J. von (1997) 'Wirtschaftspolitische Aspekte der Osterweiterung der EU', in T. König, E. Rieger and H. Schmitt (eds) Europäische Institutionenpolitik, Frankfurt a.M.: Campus (Mannheimer Jahrbuch zur Europäischen Sozialforschung, vol. II), 380-96.

Hosli, M.O. (1996) 'Coalitions and power: effects of qualified majority voting in the Council of the European Union', Journal of Common Market Studies 34: 255-73. 
Johnston, M. (1994) The European Council, Oxford: Westview.

Kapteyn, P. and P. Verloren van Themaat (1990) Introduction to the Law of the European Communities, Deventer: Kluwer (2nd edition).

König, T. (1996) 'The constitutional development of European integration', Journal of Theoretical Politics 8: 553-9.

König, T. (1997) Europa auf dem Weg zum Mehrheitssystem. Gründe und Konsequenzen nationaler und parlamentarischer Integration, Opladen: Westdeutscher Verlag.

König, T. and T. Bräuninger (1998) 'The inclusiveness of European decision rules', Joumal of Theoretical Politics 10: 125-41.

Lane, J.-E. and R. Mæland (1995) 'Voting power under the EU constitution', Journal of Theoretical Politics 7: 223-30.

Lane, J.-E., R. Mæland and S. Berg (1995) 'The EU Parliament: seats, states and political parties', Journal of Theoretical Politics 7: 395-400.

Ludlow, P. (1991) 'The European Commission', in R.O. Keohane and S. Hoffman (eds) The New European Community: Decision Making and Institutional Change, Boulder, CO: Westview, 85-132.

Michalski, A. and H. Wallace (1992) The European Challenge of Enlargement, London: Royal Institute of International Affairs.

Nugent, N. (1994) The Government and Politics of the European Union, Houndmills: Macmillan (3rd edition).

Sabsoub, J.-P. (1991) The Council of the European Community, Luxembourg: Office for Official Publications of the European Communities.

Schneider, G. (1995) 'The limits of self-reform: institution-building in the European Union', European Journal of International Relations 1: 59-86.

Shepsle, K.A. (1986) 'Institutional equilibrium and equilibrium institutions', in H.F. Weisburg (ed.) Political Science: The Science of Politics, New York: Agathon, 51-82.

Spence, D. (1994) 'Structure, functions and procedures in the Commission', in G. Edwards and D. Spence (eds) The European Commission, Essex: Longman, 92-116.

Steunenberg, B. (1994) 'Decision making under different institutional arrangements: legislation by the European community', Journal of Institutional and Theoretical Economics 150: 642-69.

Steunenberg, B. (1997) 'Reforming legislative decision making in the European Union: an analysis of the codecision procedure and its alternatives', Enschede: University of Twente, unpublished manuscript.

Streit, M.E. and S. Voigt (1996) 'Toward ever closer union - or ever larger? Or both?', in D. Schmidtchen and R. Cooter (eds) Constitutional Law and Economics of the European Union, Cheltenham: Elgar, 223-47.

Sutter, M. (2000) 'Fair allocation and re-weighting of votes and voting power in the EU before and after the next enlargement', Journal of Theoretical Politics 12: 433-49.

Tsebelis, G. (1990) Nested Games, Berkeley: University of California Press.

Tsebelis, G. (1994) 'The power of the European Parliament as a conditional agenda setter', American Political Science Review 88: 128-42.

Tsebelis, G. (1996) 'More on the European Parliament as a conditional agenda setter: response to Moser', American Political Science Review 90: 839-44.

Tsebelis, G. and G. Garrett (1996) 'Agenda setting power, power indices and decision making in the European Union', International Review of Law and Economics 16: 345-61.

Tsebelis, G. and G. Garrett (1997) 'Why power indices cannot explain decision making in the European Union', in D. Schmidtchen and R. Cooter (eds) Constitutional Law and Economics of the European Union, Cheltenham: Elgar, 11-31.

Usher, J. (1994) 'The Commission and the law', in G. Edwards and D. Spence (eds) The European Commission, Essex: Longman, 146-68.

Westlake, M. (1994) The Commission and the Parliament, London: Butterworths.

Widgrén, M. (1995) National Interest, EU Enlargement and Coalition Formation, Helsinki: The Research Institute of the Finnish Economy. 